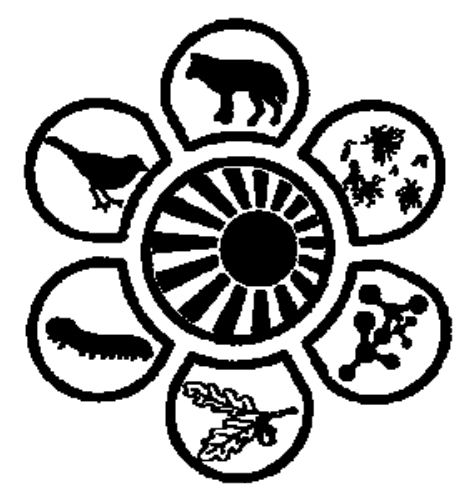

Вісник Дніпропетровського університету. Біологія, екологія.

Vìsnik Dnìpropetrovs'kogo unìversitetu. Seriâ Bìologiâ, ekologiâ

Visnyk of Dnipropetrovsk University. Biology, ecology.

Vìsn. Dnìpropetr. Unìv. Ser. Bìol. Ekol. 2014. 22(1), 71-76.

doi: $10.15421 / 011410$

ISSN 2310-0842 print

ISSN 2312-301X online

www.ecology.dp.ua

УДК 581.13: 577.15/581.45

\title{
Сезонна динаміка антиоксидантних процесів у листках Acer negundo за дії полютантів
}

\author{
Н.О. Хромих, В.С. Більчук, Г.С. Россихіна-Галича, О.М. Вінниченко
}

\section{Дніпропетровський наиіональний університет ім. Олеся Гончара, Дніпропетровськ, Украӥна}

\begin{abstract}
Досліджено сезонну динаміку активності ферментів антиоксидантного захисту в листках Acer negundo L. 3 міських екосистем iз різними типами антропогенного забруднення. Найзначніші зміни сезонної динаміки активності суперокисддисмутази (SOD, EC 1.15.1.1) і каталази (САТ, ЕС 1.11.1.6) відбувались у листках за впливу вихлопів вантажівок і промислових викидів. Динаміка активності пероксидази (POD, ЕC 1.11.1.7) змінювалась несуттєво за зростання іiї кореляції з динамікою активності САТ, що відбиває узгодженість метаболічних шляхів знешкодження перекису водню за переважання каталазного в листках із забруднених ділянок. Виявлено різкі відмінності динаміки активності глутатіонпероксидази (GPX, EC 1.11.1.9) за всіх типів забруднення при посиленні iï кореляції $з$ динамікою SOD. За незначних змін динаміки активності глутатіон-S-трансферази (GST, EC 2.5.1.18) за дії полютантів посилився іiі від’ємний кореляційний зв'язок із динаміками активності SOD та GPX. Виявлені закономірності вказують на координованість антиоксидантного захисту за дії полютантів як ознаку метаболічної стійкості виду A. negundo.
\end{abstract}

Ключові слова: Acer negundo; супероксиддисмутаза; каталаза; пероксидаза; глутатіонпероксидаза; глутатіон-S-трансфераза

\section{Seasonal dynamics of antioxidative processes in Acer negumdo leaves under pollutant action}

\author{
N.A. Khromykh, V.S. Bilchuk, G.S. Rossykhina-Galycha, O.M. Vinnychenko \\ Oles Honchar Dnipropetrovsk National University, Dnipropetrovsk, Ukraine
}

Activity of superoxide dismutase (SOD, EC 1.15.1.1), catalase (CAT, EC 1.11.1.6), peroxidase (POD, EC 1.11.1.7), glutathione peroxidase (GPX, EC 1.11.1.9) and glutathione-S-transferase (GST, EC 2.5.1.18) were measured by spectrophotometrical method in Acer negundo leaves collected during May-August in DNU Botanical garden (control) and in Dnipropetrovsk polluted ecocenoses (plots 1,2 and 3) in order to reveal the conformities of seasonal dynamics changes of antioxidative processes under pollutant action. The seasonal dynamics of SOD activity altered significantly under chronic pollutant action especially in leaves from plots contaminated by Lorries exhaust fumes and industrial emissions ( $r=0.45, r=0.08$ and $r=0.25$, accordingly, on plots 1, 2 and 3$)$. The dynamics of CAT activity because of car exhaust fumes influence was similar to control $(r=0.92)$, whereas it changed more considerably under influence of two other types of contamination $(r=0.80)$. POD activity seasonal dynamics altered insignificantly in all polluted plots, and it may indicate the predomination of catalase pathway of hydrogen peroxide detoxification in Acer negundo leaves against the background of pollutant action. Furthermore, the increasing of correlative coefficients of seasonal dynamics of CAT and POD activity (from $r=-0.18$ on control to $r=0.28, r=0.64$ and $r=0.73$, accordingly, on plots 1,2 and 3) may indicate more coordinative functioning of catalase and peroxidase metabolic pathways as adaptive sign of trees from polluted urbocenoses. The seasonal dynamics of GPX activity in tree leaves sgarply varied from control subject to all contaminated plots $(r=0.04, r=-0.97$ and $r=-0.78)$, and it was followed by enhancing positive correlative links between dynamics of GPX and SOD activities (from $r=-0.60$ on control to $r=0.51, r=0.70$ and $r=0.93$ on polluted plots). The dynamics of GST activity in A. negundo leaves did not change under pollutants action, instead of this correlative analysis revealed the intensification of negative links of GST dynamics with SOD (from $r=0.03$ on control to $r=-0.85, r=0.98$ and $r=0.93$ on plots 1, 2 and 3 ) and GPX dynamics (from $r=0.25$ on control to $r=-0.88, r=-0.56$ and $r=-0.80$ on plots 1,2 and 3). The established conformities indicate the coordination of antioxidative processes in A. negundo leaves against the background of combined chronic pollutant action and may be considered as the index of $A$. negundo species metabolic resistance to anthropogenic pollution of urban cenoses.

Keywords: Acer negundo; superoxide dismutase; catalase; peroxidase; glutathione peroxidase; glutathione-S-transferase

Дніпропетровський національний університет імені Олеся Гончара, пр. Гагаріна, 72, Дніпропетровськ, 49010, Украӥна.

Oles Honchar Dnipropetrovsk National University, Gagarin Ave., 72, Dnipropetrovsk, 49010, Ukraine.

Tel.: +38-050-487-87-17. E-mail: Khromykh2012@gmail.com 


\section{Вступ}

У міських екосистемах рослини одночасно з дією природних факторів зазнають хронічного впливу техногенних чинників, таких як сполуки важких металів, оксиди азоту та сірки, вуглеводні, феноли, пил (Slushyk, 2005; Zeiger, 2006; Yadav, 2010; Bobyliov et al., 2014), які потрапляють у рослини через забруднені повітря, воду та грунт. Несприятлива дія полютантів на рослини позначається скороченням періоду їх вегетації, гальмуванням ростових процесів, зменшенням площі асиміляційних органів (Wierzbicka and Obidzinska, 1998; Bezsonova, 2001), зниженням вмісту фотосинтезувальних пігментів у листках (Deniz and Duzenli, 2007; Garifzyanov and Ivanyschev, 2011), порушенням фізіологічних i біохімічних регуляторних систем (Kulagin, 2002; Ramel et al., 2012). За дії стресорів онтогенез рослин забезпечується винятково за рахунок активації захисних ресурсів на різних рівнях організації рослинних організмів (Polle, 2000; Zang and Gallie, 2005; Kolupaev and Karpets, 2010), що зумовлює їх адаптацію до несприятливих умов середовища.

Стійкість рослин до впливу токсикантів визначається здатністю метаболічних систем як до їх знешкодження, так і до відновлення клітинного гомеостазу (Chirkova, 2004; Geraskin et al., 2011), у зв'язку з чим особливого значення набуває вивчення функціонування клітинних захисних механізмів. Неспецифічні стресові реакції рослин асоціюються 3 посиленим утворенням у клітинах активних форм кисню (АФК), таких як супероксиданіон $\left(\mathrm{O}_{2}^{\circ}\right)$, перекис водню $\left(\mathrm{H}_{2} \mathrm{O}_{2}\right)$ та гідропероксиди ліпідів (Faltin et al., 2010). Оскільки ці метаболіти здатні до окислювального ушкодження білків, ліпідів, нуклеїнових кислот та інших біологічних макромолекул (Zhang et al., 2007), їх внутрішньоклітинний рівень контролюється за допомогою антиоксидантних систем (Gill and Tuteja, 2010). Ферменти, які входять до їх складу (супероксиддисмутаза, SOD; каталаза, CAT; пероксидаза, POD; глутатіонпероксидаза, GPX), забезпечують нейтралізацію АФК, а також знешкодження екзогенних токсикантів (глутатіон-S-трансфераза, GST), що $є$ передумовою відновлення клітинного гомеостазу за дії стресорів і формування метаболічної адаптації рослин до несприятливих умов середовища (Chang et al., 2009; Ramel et al., 2012).

За умов урбанізації зростає роль рослинності в очищенні повітря від викидів підприємств і транспорту (Kulagin, 2002; Geraskin et al., 2011; Matyssek et al., 2012), тому під час створення міських фітоценозів необхідно не тільки враховувати декоративні якості рослинних видів, a i прогнозувати їх стійкість до впливу полютантів. У фітоценозах промислових міст широко розповсюджені представники роду Acer L., які володіють підвищеною стійкістю до задимлення та загазованості повітря (Bezsonova, 2001), зокрема, A. negundo (Linnaeus, 1753) має низький і середній рівні чутливості за ступенем пошкодження асиміляційних органів (Korshykov et al., 1995), однак клітинні механізми стійкості цього виду до впливу полютантів не досліджено. Системне вивчення функціонального стану рослин за несприятливих умов середовища доцільно проводити протягом онтогенезу рослин (Polovnikova and Voskresenskaya, 2008; Kardel et al., 2012; Nehnevajova et al., 2012), проте нині таких досліджень бракує. Мета роботи полягає у з'ясуванні закономірностей варіювання сезонної динаміки активності антиоксидантних ферментів у листках A. negundo за умов антропогенного забруднення.

\section{Матеріал і методи досліджень}

Дослідження проведено на листках клена ясенолистого (A. negundo), відібраних у Ботанічному саду ДНУ (контроль) i в антропогенно забруднених міських фітоценозах: вихлопами легкового транспорту (ділянка 1), вихлопами легкового та вантажного транспорту (ділянка 2), вихлопами вантажівок і промисловими викидами (ділянка 3). Листки відбирали 3 однорічних пагонів із 3-5 дерев близького вікового стану на висоті 2,0-2,5 м від поверхні грунту, у період із травня по серпень на початку кожного місяця. Активність ферментів визначали в супернатантах, отриманих після центрифугування рослинних екстрактів (15000 об./хв протягом 20 хв за $\left.+4{ }^{\circ} \mathrm{C}\right)$, і перераховували на 1 г сирої маси зразка.

Активність супероксиддисмутази визначали згідно 3 (Shupranova et al., 2011) за рівнем гальмування процесу відновлення нітросинього тетразолію (NBT). Реакційна суміш містила $0,1 \mathrm{M}$ фосфатний буфер, розчини NBT i $\mathrm{NADH}$ (нікотинамідаденіндинуклеотиду), а також супернатант. Реакцію зупиняли додаванням оцтової кислоти, оптичну густину вимірювали при 540 нм, результати рахували в умовних одиницях.

Активність каталази визначали титриметричним методом за (Shupranova et al., 2011) із використанням розчину перманганату калію після інкубування супернатанту протягом 30 хв за $+25^{\circ} \mathrm{C}$ з пероксидом водню, результати рахували в мМоль $\mathrm{H}_{2} \mathrm{O}_{2} /$ хв.

Пероксидазну активність у листках визначали згідно 3 (Shupranova et al., 2011) за швидкістю окислення розчину бензидину, зміни оптичної густини реакційної суміші реєстрували при 470 нм, активність ферменту рахували в одиницях оптичної густини/хв.

Активність глутатіон-S-трансферази вимірювали за (Habig et al., 1974) спектрофотометричним методом за довжини хвилі 340 нм за здатністю до кон'югації хлординітробензолу (CDNB) з відновленим глутатіоном, і рахували в нМоль CDNB, перетвореного за секунду (нкатал). Активність глутатіон-пероксидази визначали згідно 3 (Navrot et al., 2006) за окисленням NADHP за присутності перекису водню, зміни оптичної густини реакційної суміші реєстрували при 340 нм протягом 4 хв, активність ферменту рахували в нМоль NADHP, окисленого за секунду (нкатал).

Результати опрацьовано статистично 3 використанням пакета програм Microsoft Excel. Розбіжності між вибірками оцінювали за $t$-критерієм Стьюдента, вважали достовірними за $P<0,05$.

\section{Результати та їх обговорення}

Функціонування супероксиддисмутази у рослинних клітинах забезпечує дисмутацію супероксидного аніона 
$\left(\mathrm{O}_{2}^{-}\right)$, який є однією з найбільш реакційноздатних АФК, 3 утворенням менш шкодочинного для клітин перекису водню (Zhang et al., 2007), тому рівень активності SOD характеризує інтенсивність першої ланки антиоксидантного захисту рослин за дії різноманітних стресорів. У листках $A$. negundo активність супероксиддисмутази у травні за всіх типів антропогенного забруднення перевищувала контрольний рівень, відповідно на 32, 56 і 71\% на ділянках 1, 2 та 3 (рис. 1).

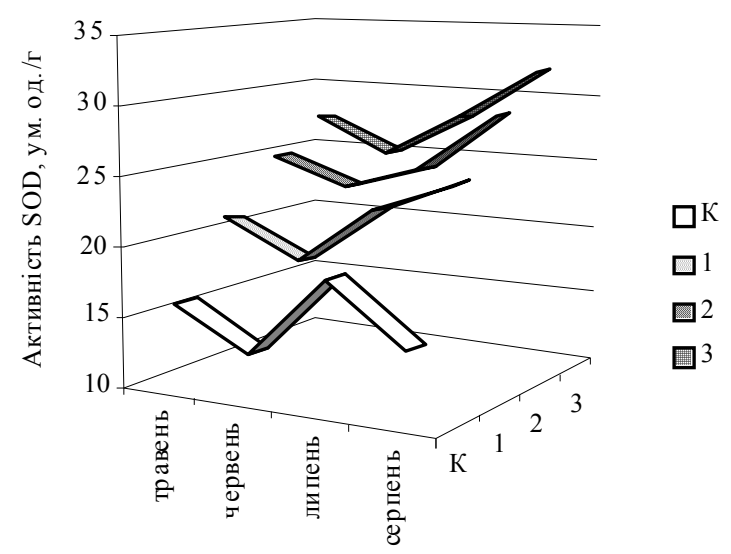

Рис. 1. Сезонна динаміка активності супероксиддисмутази у листках $A$. negundo: $K$ - Ботанічний сад ДНУ, 1 - за впливу вихлопів легкового транспорту, 2 - за впливу вихлопів легкового та вантажного транспорту, 3 - за впливу вихлопів вантажівок і промислових викидів

Тенденція до перебільшення контрольного рівня зберігалась на фоні зниження ферментативної активності в листках кленів з усіх фітоценозів у червні та ії зростанні у липні. У серпні на фоні падіння активності SOD у листках із контрольного фітоценозу відмічена суттєва активація ферменту в листках 3 усіх забруднених фітоценозів (відповідно, на 68, 94 і 113\% вище контролю). Таким чином, вплив полютантів змінював як рівні, так і сезонну динаміку активності супероксиддисмутази, що підтверджують низькі коефіцієнти кореляції 3 контролем: $r=0,45, r=0,08$ і $r=0,25$, відповідно для листків із забруднених ділянок 1,2 і 3.

Накопичення перекису водню токсичне для клітин, i його знешкодження забезпечується завдяки функціонуванню каталази, яка розкладає молекули токсиканта на воду та молекулярний кисень, різноманітних пероксидаз, які перетворюють $\mathrm{H}_{2} \mathrm{O}_{2}$ завдяки окисненню органічних косубстратів та антиоксидантів (Zhang et al., 2007). За впливу несприятливих чинників ступінь активації оксидоредуктаз відбиває ефективність антиоксидантного захисту рослинних клітин (Kolupaev and Karpets, 2010).

У листках A. negundo 3 ділянок 1, 2 і 3 активність каталази (рис. 2) набагато перевищувала контрольний рівень: у травні на 65, 80 і 95\% відповідно, у червні перевищення дещо знижувалось - 59, 64 і 74\%.

У листках клена в контрольному фітоценозі та в забрудненому вихлопами легкового транспорту активність каталази після різкого зростання у червні надалі помітно знижувалась, при цьому в липні та серпні активність ферменту у листках із забрудненої ділянки перебільшувала контрольний рівень на 129 і $137 \%$ відповідно. Навпаки, у листках із забруднених фітоценозів 2 та 3 ферментативна активність каталази у липні зростала, перебільшуючи контроль відповідно на 186 та 200\%; у серпні на ділянці 2 перебільшення становило 165\% вище контролю, тоді як на ділянці 3 - 203\% вище контролю. Тобто сезонна динаміка активності САТ у листках за дії вихлопів легкового транспорту була близькою до контрольної, проте помітніше змінювалась за інших типів забруднення, про що свідчать коефіцієнти кореляції 3 контролем: $r=0,92, r=0,80$ і $r=0,80$, відповідно для забруднених ділянок 1, 2 і 3.

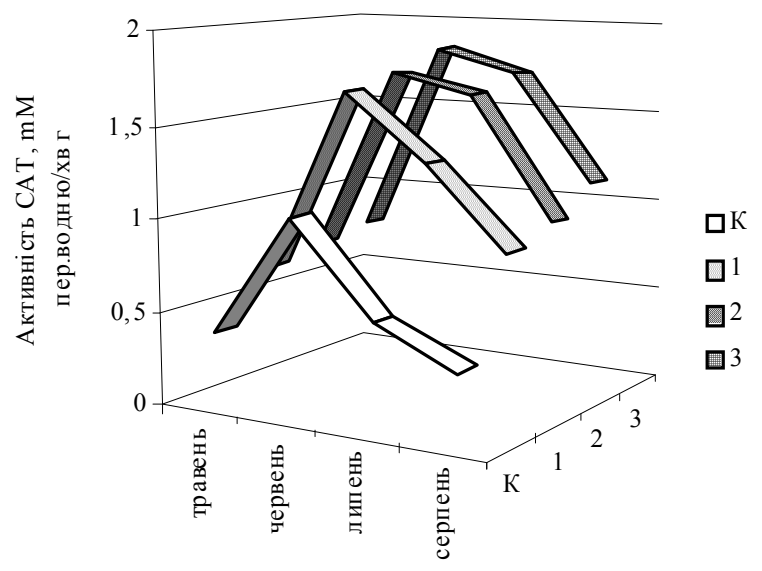

Рис. 2. Сезонна динаміка активності каталази у листках $\boldsymbol{A}$. negundo: позначення див. рис. 1

Пероксидазна активність (рис. 3) у листках A. negundo 3 ділянок 1, 2 і 3 суттєво перевищувала контрольний рівень: відповідно, у травні на 82, 119 і 147\%, а в червні на 47, 117 і 153\%. У липні та серпні перевищення контрольної активності ферменту у листках із забрудненого фітоценозу 1 було недостовірним, а в листках із ділянок 2 та 3 становило лише 21-35\%. Отже, вплив полютантів спричинював активацію POD у листках клена ясенолистого, не змінюючи сезонної динаміки активності ферменту на забруднених ділянках 1, 2 та 3, для кожної $з$ яких установлено високий рівень кореляції з контролем: $r=0,99, r=0,97$ і $r=0,94$, відповідно.

Здатність до активації пероксидази та каталази у рослинних клітинах дослідники асоціюють зі стійкістю до стресу, спричиненого забрудненням середовища промисловими викидами, у таких видів, як Populus balsamifera (Kulagin, 2002), Acer platanoides (Garifzyanov and Ivanyschev, 2011), Robinia pseudoacacia (Khromykh and Rossikhina, 2011). Значне зростання каталазної та пероксидазної активності у листках $A$. negundo 3 антропогенно забруднених фітоценозів вказує на здатність до активації захисних антиоксидантних механізмів упродовж усього періоду вегетації рослин, що, імовірно, сприяє підвищенню стійкості рослин до хронічного впливу комплексу полютантів.

Пероксидази надто чутливі до концентрації перекису водню, тому їх активність може зростати навіть за незначного збільшення вмісту $\mathrm{H}_{2} \mathrm{O}_{2}$, тоді як каталаза активується за відносно більшого накопичення токсиканта, і такий перерозподіл активності оксидоредуктаз за дії стресорів пов'язують 3 ефективністю антиоксидантного захисту у рослинних клітинах (Mika et al., 2004; Polovnikova and Voskresenskaya, 2008). У зв'язку із цим досліджено взаємний зв'язок між сезонними змінами 
рівнів активності CAT та POD у листках $A$. negundo в контрольному та забруднених фітоценозах. За відсутності впливу полютантів коефіцієнт кореляції був незначний від'ємний $(r=-0.18)$, тоді як на ділянках 1,2 і 3 зростав залежно від типу забруднення (відповідно, $r=$ 0,28, $r=0,64$ і $r=0,73)$. Тобто за хронічної дії полютантів у листках клена ясенолистого посилювалась координованість функціонування пероксидази та каталази, що, імовірно, сприяло стійкості рослин до впливу забруднювачів.

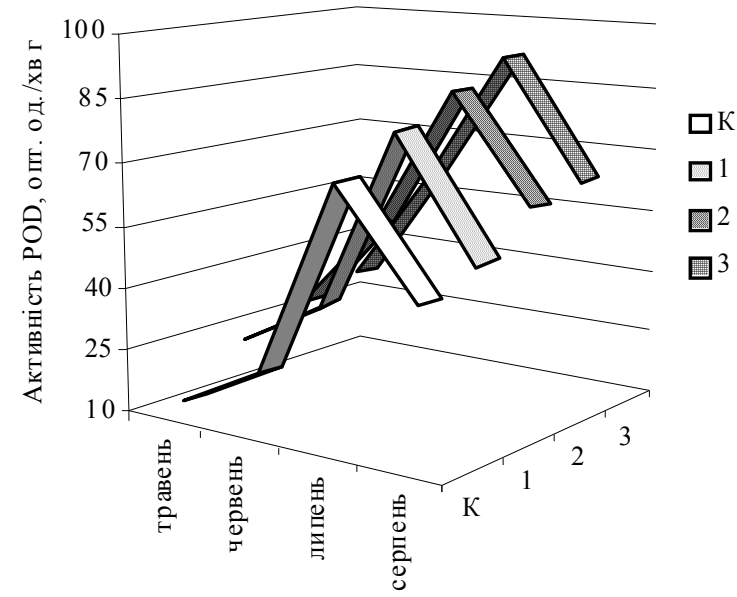

Рис. 3. Сезонна динаміка активності пероксидази у листках $\boldsymbol{A}$. negundo: позначення див. рис. 1

Рослинні глутатіонпероксидази здатні (на додаток до пероксиду водню) відновлювати гідропероксиди фосфоліпідів та ліпідного комплексу біомембран, а також інші органічні гідропероксиди (Faltin et al., 2010), що визначає ключову роль цих ферментів в антиоксидантному захисті клітинних мембран і формуванні толерантності до стресів (Chang et al., 2009).

У листках $A$. negundo за контрольних умов у травні виявлено невисоку активність глутатіонпероксидази та іiі повільне зниження протягом вегетації (рис. 4), що узгоджується 3 даними G. Noctor зі співавторами (Noctor et al., 2002) про незначну активність рослинних GPX за відсутності впливу стресорів.

Індукована впливом полютантів активність GPX у листках із забруднених фітоценозів 1, 2 та 3 суттєво перевищувала контрольний рівень: відповідно, у травні на 29,31 і 110\%, у червні на 25, 38 і 119\%. У липні в листках із фітоценозу, забрудненого вихлопами легкового транспорту, активність GPX зростала відносно контролю лише на $38 \%$, тоді як на ділянках 2 і 3 вона сягала відповідно 181 і 289\% вище контролю. У серпні ж активність ферменту в забруднених фітоценозах набувала максимальних значень, і перебільшення контрольного рівня становило 137, 157 і 325\%, відповідно для ділянок 1,2 та 3.

Сезонна динаміка активності глутатіонпероксидази в листках $A$. negundo за дії полютантів суттєво відрізнялась від контрольної залежно від типу забруднення, на що вказують коефіцієнти кореляційного зв'язку (відповідно, $r=0,04, r=-0,97$ і $r=-0,78$ на ділянках 1, 2 та 3). Натомість вплив полютантів супроводжувався посиленням позитивного кореляційного зв'язку між сезонними динаміками активності GPX та
SOD (від $r=-0,60$ у контролі до $r=0,51, r=0,70$ i $r=$ 0,93 відповідно у фітоценозах 1, 2 та 3). Імовірно, вплив полютантів одночасно спричинював інтенсифікацію процесів знешкодження супероксидного аніона та гідропероксидів у рослинних клітинах не тільки у фазі активного росту листків, а й у фазі переходу до фізіологічного спокою. Можна припустити, що здатність $A$. negundo до суттєвої та координованої активації SOD і GPX у листках протягом вегетації $\epsilon$ проявом метаболічної стійкості рослин до хронічного комплексного впливу полютантів.

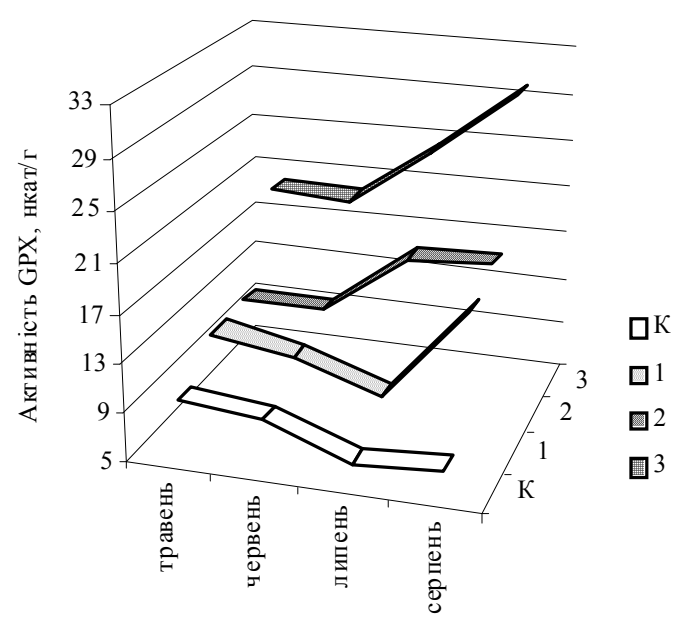

Рис. 4. Сезонна динаміка активності глутатіонпероксидази у листках $A$. negundo: позначення див. рис. 1

Глутатіон- $S$-трансферази $\in$ великою родиною ферментів, які мають велике протекторне значення в рослинних клітинах завдяки здатності до детоксикації різноманітних ксенобіотиків шляхом їх кон'югації 3 відновленим глутатіоном і подальшої локалізації кон'югатів у вакуолях (Edwards et al., 2000), а також відіграють ключову роль у вторинному метаболізмі рослин (Dixon et al., 2010).

У листках A. negundo у травні виявлено високу активність GST у всіх фітоценозах, при цьому на забруднених ділянках 1, 2 та 3 активність ферменту перевищувала контрольне значення лише на 12, 17 і 15\% відповідно (рис. 5). Слід відзначити високий контрольний рівень активності GST у листках $A$. negundo, принаймні значно більший, ніж виявлена нами раніше (Khromykh and Rossikhina, 2011) контрольна активність ферменту у листках Robinia pseudoacacia. Можливо, тому для ефективного знешкодження полютантів у листках клена ясенолистого було достатньо незначної активації ферменту.

Максимальний рівень активності GST виявлено у червні в листках з усіх ділянок, надалі відбувалось поступове зниження ферментативної активності, яке завершилось іiі різким зменшенням у серпні, причому перебільшення контрольного рівня у цей період не було достовірним. Тобто хронічний вплив полютантів викликав у листках $A$. negundo активацію GST, проте майже не змінював сезонної динаміки активності ферменту порівняно з динамікою в контрольному фітоценозі, що підтверджують коефіцієнти кореляції з контролем: $r=$ 0,99 для листків з усіх забруднених ділянок. 


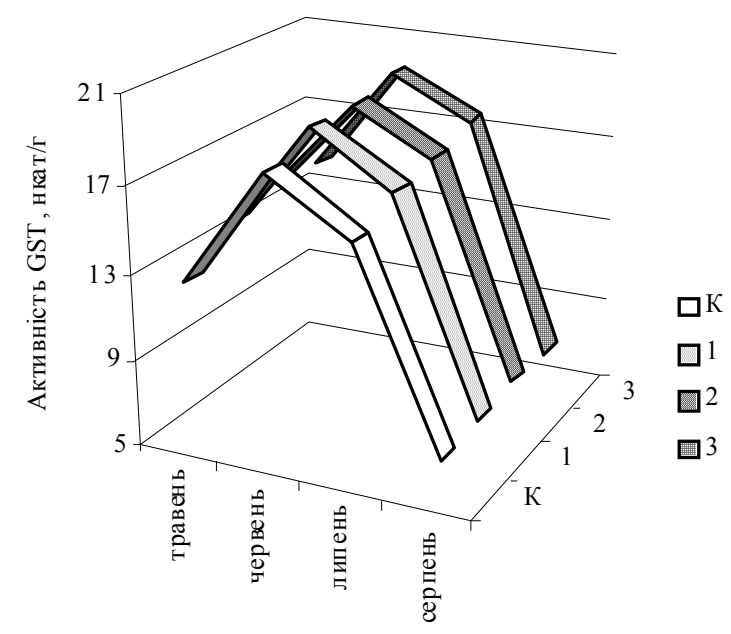

Рис. 5. Сезонна динаміка активності глутатіон-S-трансферази у листках $A$. negundo: позначення див. рис. 1

Кореляційний аналіз також виявив посилення від'ємного зв'язку між сезонною динамікою активності GST i SOD (від $r=0,03$ у контролі до $r=-0,85, r=-0,98$ i $r=-0,93$, відповідно на ділянках 1,2 та 3) та активності GST i GPX (від $r=0,25$ у контролі до $r=-0,88, r=-0,56$ i $r=-0,80$, відповідно на ділянках 1,2 та 3). Установлені коефіцієнти можна вважати проявом узгодженості метаболічних процесів у листках $A$. negundo за хронічної дії полютантів: у фазі активного росту рослин інтенсивне функціонування GST забезпечує зменшення накопичення токсикантів у клітинах та уповільнення процесу утворення АФК, що супроводжується зниженням інтенсивності їх знешкодження завдяки SOD i GPX; у серпні, навпаки, зниження активності GST у листках спричинювало активацію процесів знешкодження АФК. Різке зростання активності GPX у листках клена ясенолистого у цей період може бути зумовлене перебудовами у функціонуванні глутатіонової захисної системи, оскільки відомо (Noctor et al., 2002), що деякі ізоформи рослинних глутатіон- $S$-трансфераз здатні також і до прояву глутатіонпероксидазної активності.

\section{Висновки}

У листках A. negundo за хронічної дії полютантів виявлено активацію ферментів антиоксидантного захисту (супероксиддисмутаза, каталаза, пероксидаза, глутатіонпероксидаза, глутатіон- $S$-трансфераза) та зміни сезонної динаміки їх активності. Сезонна динаміка активності SOD зазнала суттєвих змін, особливо у листках із ділянок, забруднених вихлопами вантажівок і промисловими викидами. Динаміка активності САТ у листках із ділянки, забрудненої вихлопами легкового транспорту, була близькою до контрольної, тоді як за інших типів забруднення помітно змінювалась. Найменшим чином за дії полютантів змінювались сезонна динаміка та рівні активності POD, що вказує на переважання каталазного шляху знешкодження перекису водню в листках $A$. negundo. Більше того, у листках клена ясенолистого iз забруднених фітоценозів виявлено посилення кореляційних зв'язків між динамікою активності САТ і
POD, що відбиває координованість функціонування ферментів і сприяє стійкості рослин до забруднювачів. Сезонна динаміка активності GPX за дії полютантів різко відрізнялась від контрольної, натомість відбувалось посилення позитивного кореляційного зв'язку між динамікою активності GPX i SOD, що може бути показником метаболічної стійкості $A$. negundo до хронічного впливу полікомпонентних викидів. Динаміка активності GST у листках не змінювалась за дії полютантів, натомість кореляційний аналіз виявив високий рівень від'ємного зв'язку сезонної динаміки GST 3 динамікою SOD та GPX. Установлені закономірності відбивають узгодженість перебудови антиоксидантних процесів у листках за хронічної дії полютантів, що може бути передумовою метаболічної адаптації дерев A. negundo до умов антропогенного забруднення екосистем.

\section{Бібліографічні посилання}

Bezsonova, V.P., 2001. Metody phytoindykatsiy v otsincy ekologichnogo stanu dovkillya [Methods of phytoindication for evaluation of environmental ecological state]. Zaporizhya University Press, Zaporizhya (in Ukrainian).

Bobyliov, Y.P., Brygadyrenko, V.V., Bulakhov, V.L., Gaichenko, V.A., Gasso, V.Y., Didukh, Y.P., Ivashov, A.V., Kucheriavyi, V.P., Maliovanyi, M.S., Mytsyk, L.P., Pakhomov, O.Y., Tsaryk, I.V., Shabanov, D.A., 2014. Ecology. Folio, Kharkiv (in Ukrainian).

Chang, C.C.C., Slesak, I., Jorda, L., Sotnikov, A., Melzer, M., Miszalski, Z., Mullineaux, P.M., Parker, J.E., Karpinska, B., Karpinski, S., 2009. Arabidopsis chloroplastic glutathione peroxidases play a role in cross talk between photooxidative stress and immune responses. Plant Physiol. 150, 670-683.

Chirkova, T.V., 2002. Phiziologicheskye osnovy ustoychivosty rasteniy [Physiological basis of plant resistance]. St.Petersburg Univ. Press, St.-Petersburg (in Russian).

Deniz, M., Duzenli, S., 2007. The effect of refinery pollution on non-enzymatic foliar defense mechanisms in four evergreen plants species in Turkey. Acta Physiol. Plant. 29, 71-79.

Dixon, D.P., Skipsey, M., Edwards, R., 2010. Molecules of interest. Roles for glutathione transferases in plant secondary metabolism. Phytochemistry 71(4), 338-350.

Edwards, R., Dixon, D.P., Walbot, V., 2000. Plant glutathione Stransferases: Enzymes with multiple functions in sickness and in health. Trends Plant Sci. 5(5), 193-198.

Faltin, Z., Holland, D., Velcheva, M., Tsapovetsky, M., Roeckel-Drevet, P., Handa, A.K., Abu-Abied, M., Friedman-Einat, M., Eshdat, Y., Perl, A., 2010. Glutathione peroxidase regulation of reactive oxygen species level is crucial for in vitro plant differentiation. Plant Cell Physiol. 51(7), $1151-1162$.

Garifzyanov, A.P., Ivanyschev, V.V., 2011. Physiologicheskye reaktsiy Acer platanoides L. na stress, vyzvannyi zagryazneniem sredy tyazhelymy metallamy [Physiological reactions of Acer platanoides L. to stress caused by heavy metals contamination of environment]. Fundamental Investigation 9, 331-334 (in Russian).

Geraskin, S., Evseeva, T., Oudalova, A., 2011. Plants as a tool for the environmental health assessment. Encyclopedia of Environmental Health. Elsevier Science. Vol. 1, 571-579.

Gill, S.S., Tuteja, N., 2010. Reactive oxygen species and antioxidant machinery abiotic stress tolerance in crop plants. Plant Physiol. Biochem. 48(12), 909-930. 
Habig, W.H., Pabst, M.J., Jakoby, W.B., 1974. Glutathione Stransferase. The first step in mercapturic acid formation. J. Biol. Chem. 249, 7130-7139.

Kardel, F., Wuyts, K., Babanezhad, M., Wuytack, T., Adriaenssens, S., Samson, R., 2012. Tree leaf wettability as passive bio-indicator of urban habitat quality. Environ Exp Botan. 75(1), 277-285.

Khromykh, N., Rossikhina, G., 2011. Sezonna dinamika aktivnosti zakhysnykh fermentiv u lystkakh Robinia pseudoacacia za umov urbocenosiv [The seasonal dynamic of protective enzymes activity in Robinia pseudoacacia leaves under urbocenoses conditions]. Pitannya Bioindicatsii ta Ecologyi 16(1), 87-93 (in Ukrainian)

Kolupaev, Y.E., Karpets, Y.V., 2010. Formirovanie adaptivnykh reaktsiy rasteniy na deystvie abioticheskikh stressorov [Formation of plants adaptive reactions to abiotic stressors influence]. Osnova, Kyiv (in Russian).

Korshikov, I.I., Kotov, V.S., Mikheenko, I.P., Ignatenko, A.A., Chernyshova, L.V., 1995. Vzaimodeistvie rasteniy s tekhnogenno zagryaznennoy sredoy [Plants interaction with contaminated environment]. Naukova Dumka, Kiev (in Russian).

Kulagin, A.A., 2002. Ekologo-phyziologicheskie osobennosty topolya balzamicheskogo (Populus balsamifera L.) v usloviyakh zagryazneniya okruzhayuschey sredy metallamy [Ecology-physiological peculiarities of Populus balsamifera L. under metals contamination of environmet]. Dissertation Essay, Toliyatty (in Russian).

Matyssek, R., Wieser, G., Calfapietra, C., Vries, W., Dizengremel, P., Ernst, D., Jolivet, Y., Mikkelsen, T.N., Mohren, G.M.J., Thies, D., Tuovinen, J.-P., Weatherall, A., Paoletti, E., 2012. Forest under climate change and air pollution: Gaps in understanding and future direction for research. Environ. Pollut. 160(1), 57-65.

Mika, A., Minibayeva, F., Beckett, R., Luthje, S., 2004. Possible functions of extracellular peroxidases in stress-induced generation and detoxification of active oxygen species. Phytochem. Rev. 3(1-2), 173-193.

Navrot, N., Collin, V., Gualberto, J., Gelhaye, E., Hirasava, M., Rey, P., Knaff, D.B., Issakidis, E., Jacquot, J.-P., Rouhier, N., 2006. Plant glutathione peroxidases are functional peroxiredoxins distributed in several subcellular compartments and regulated during biotic and abiotic stresses. Plant Physiol. 142, 1364-1379.

Nehnevajova, E., Lyubenova, L., Herzig, R., Schroder, P., Schwitzguebel, J.-P., Schmulling, T., 2012. Metal accumulation and response of antioxidant enzymes in seedlings and adult sunflower mutants with improved metal removal traits on a metal-contaminated soil. Environ. Exp. Bot. 76(2), $39-48$.

Noctor, G., Gomez, L., Vanacker, H., Foyer, C.H., 2002. Interaction between biosynthesis, compartmentation and transport in the control of glutathione homeostasis and signaling. J. Exp. Bot. 53(372), 1283-1304.

Polle, A., 2000. Defence against photooxidative damage in plants. In: Oxidative stress and the molecular biology of antioxidant defence / Ed. Scandallious. Cold Spring Harbour Lab. Press, 623-666.

Polovnikova, M.G., Voskresenskaya, O.L., 2008. Aktivnost komponentov antioksidantnoy zaschity i polifenoloksidazy $u$ gazonnykh rasteniy $\mathrm{v}$ ontogeneze $\mathrm{v}$ usloviyakh gorodskoy sredy [Activity of antioxidative defense components and polyphenoloxidase of lawn plants during ontogenesis under urban conditions]. Physiology of Plants 55(5), 777-785 (in Russian).

Ramel, F., Sulmon, C., Serra, A.A., Gouesbet, G., Couee, I., 2012. Xenobiotic sensing and signaling in higher plants. J. Exp. Bot. 63(11), 3999-4014.

Shupranova, L.V., Bilchuk, V.S., Boguslavska, L.V., Rossykhina, G.S., Vinnychenko, O.M., 2011. Suchasni metody biochimichnogo analizu roslyn [Modern methods of plants biochemical analysis]. Dnipropetrovsk University Press, Dnipropetrovsk (in Ukrainian).

Sluchyk, I., 2005. An estimation of the urban system's mutagenic background using Populus berolinensis Dipp. Visnik of L'viv Univ. Biology series 39, 66-70 (in English).

Wierzbicka, M., Obidzinska, J., 1998. The effect of lead on seed imbibition and germination in different plant species. Plant Sci. 137, 155-171.

Yadav, S.K., 2010. Heavy metals toxicity in plants: An overview on the role of glutathione and phytochelatins in heavy metal stress tolerance of plants. S. Afr. J. Bot. 76(2), 167-179.

Zang, C., Gallie, D.R., 2005. Increasing tolerance to ozone by elevating foliar ascorbic acid confers greater protection against ozone than increasing avoidance. Plant Physiol. $138(3), 1673-1689$.

Zeiger, E., 2006. The effect of air pollution on plants. Plant Physiology. Fifth Edition. Essay 26.1. Online.

Zhang, G., Tanakamaru, K., Abe, J., Morita, S., 2007. Influence of waterlogging on some anti-oxidative enzymatic activities of two barley genotypes differing in anoxia tolerance. Acta Physiol. Plant. 29, 171-176.

Надійшла до редколегї̈ 29.04.2014 